\title{
TINDAK TUTUR DIREKTIF ANAK AUTIS
}

\author{
Endang Sumarti dan Umi Salamah \\ FISH IKIP Budi Utomo Malang \\ e-mail: endangsumarti@yahoo.com.
}

\begin{abstract}
Abstrak
Penelitian ini bertujuan mendeskripsikan bentuk, fungsi, dan strategi tindak tutur direktif anak autis. Data penelitian berupa rekaman dialog tuturan anak autis di sekolah autis dan sekolah inklusi di Kota Malang. Pengumpulan data menggunakan teknik pengamatan dan perekaman. Pengumpulan dan analisis data dikerjakan secara interaktif, serempak, dan berulang-ulang untuk menghasilkan pemahaman yang mendalam dan utuh tentang bentuk, fungsi, dan strategi tindak tutur direktif anak autis. Hasil penelitian sebagai berikut. Pertama, bentuk tindak tutur direktif anak autis meliputi tindak tutur permintaan, tindak tutur perintah, dan tindak tutur larangan. Kedua, fungsi komunikatif tindak tutur direktif anak autis meliputi fungsi meminta, fungsi memerintah, dan fungsi melarang. Ketiga, strategi penggunaan tindak tutur direktif anak autis meliputi strategi langsung dan strategi tidak langsung.
\end{abstract}

Kata kunci: tindak tutur, direktif, anak autis

\section{AUTISTIC CHILDREN'S DIRECTIVE SPEECH ACTS}

\begin{abstract}
This study aims to describe forms, functions, and strategies in autistic children's directive speech acts. The data were from the recording of dialogs performed in an autism-specific school and an inclusive school in Malang City. They were collected through observations and recording. The data collection and analysis were interactively, simultaneously, and iteratively done to deeply and wholly understand forms, functions, and strategies in autistic children's directive speech acts. The results of the study are as follows. First, the forms include requests, commands, and prohibitions. Second, the functions comprise those of requesting, commanding, and prohibiting. Third, the strategies consist of a direct strategy and an indirect strategy.
\end{abstract}

Keywords: speech acts, directive, autistic children

\section{PENDAHULUAN}

Tindak tutur direktif merupakan salah satu dari jenis tindak tutur yang digunakan anak autis dalam interaksi pembelajaran di kelas. Tindak tutur direktif lebih banyak digunakan anak autis dalam berinteraksi dengan mitra tuturnya dibandingkan dengan tindak tutur asertif dan ekspresif (Sumarti, 2012). Tingginya tingkat penggunaan bentuk tindak tutur direktif anak autis ketika berinteraksi dengan mitra tuturnya sebagaimana dikemukakan di atas tidak terlepas dari karakteristik anak autis (Cumings, 2009).

Anak autis tidak mampu mengekspresikan keinginannya secara spontan (Prasetyono, 2008). Beberapa anak autis tidak mampu berbicara, tidak mampu mengekspresikan diri, baik melalui bahasa verbal maupun nonverbal, terlihat sangat asyik dengan dirinya sendiri, minatnya terbatas, dan sama sekali tidak tertarik 
dengan lingkungannya. Kekebalan tubuh tidak berkembang sebagaimana seharusnya, berinteraksi jika membutuhkan sesuatu, berkomunikasi dengan tertawa dan menangis, sangat hiperaktif, tidak mau digandeng di tempat umum, menolak diarahkan, bahkan menolak disentuh, dan dipegang (Yatim, 2003; Williams 2004; Puspita, 2004)

Untuk menyampaikan keinginannya anak autis menggunakan perilaku verbal yang sangat sederhana, yakni satu atau dua kata yang diikuti dengan perilaku nonverbal (Dompas, 2008). Untuk meminta sesuatu yang diinginkan, anak autis menggunakan bentuk verbalnya sambil melakukan gerakan-gerakan tertentu yang mendukung ujarannya sebagaimana dapat dilihat pada contoh berikut.

G : "Apakah spidol ini warna merah?".

(1) (guru menunjukkan spidol warna hitam)

AA : "Sakit kepala! Sudah, sudah! Sakit kepala! ". (2)

Konteks : Dituturkan Guru dalam interaksi pembelajaran di kelas waktu siang hari, saatnya anak mau istirahat.

Dari tuturan di atas, dapat dilihat bahwa anak autis menggunakan bentuk tindak tutur direktif berfungsi memerintah guru dengan menggunakan strategi penggunaan tuturan langsung dan tidak langsung. Bentuk tindak tutur direktif berupa perintah langsung dapat dilihat pada tuturan (2). Dengan menggunakan tuturan "sudah!" penutur menggunakan bentuk tindak tutur direktif berupa perintah langsung kepada mitra tutur. Selain itu, penutur juga menggunakan tuturan perintah tidak langsung sebagaimana dapat dilihat pada contoh (2). Agar mitra tutur menghentikan tanya jawab tersebut, penutur mengungkapkan tuturan pernyataan "Sakit kepala" agar mitra tutur menghentikan pertanyaannya. Untuk bisa mengungkapkan keinginannya perlu dilakukan latihan dan terapi secara berkesinambungan.

Pembelajaran dan terapi anak autis ditujukan untuk bisa berkomunikasi, minimal untuk memenuhi kebutuhannya (Maulana, 2007). Untuk bisa memenuhi kebutuhannnya anak autis dituntut untuk bisa mengungkapkan maksudnya melalui bahasa. Dengan mengetahui berbagai bentuk, fungsi, dan strategi tindak tutur direktif anak autis, guru dapat meningkatkan kualitas pembelajaran agar anak autis bisa berkomunikasi dengan baik.

Berkaitan dengan hal tersebut yang menarik untuk dikaji adalah bagaimanakah tindak tutur direktif anak autis. Walaupun anak autis mengalami gangguan komunikatif dalam penggunaan bahasa, namun anak autis perlu untuk berkomunikasi dengan sesama, baik dengan orang tua, teman sebayanya, atau orang-orang di sekitar mereka.

Berdasarkan paparan di atas, secara operasional, fokus penelitian tindak tutur direktif anak autis dirumuskan berikut ini. Pertama, bentuk tindak tindak tutur direktif anak autis. Kedua, fungsi komunikatif tindak tutur direktif anak autis. Ketiga, strategi penggunaan tindak tutur direktif anak autis.

\section{METODE}

Penelitian ini menggunakan pendekatan kualitatif. Data penelitian ini berupa rekaman dialog tuturan anak autis yang disikapi sebagai simbol-simbol kebahasaan yang mengkonstruk: (1) bentuk tindak tutur direktif anak autis, (2) fungsi komunikatif tindak tutur direktif anak autis, dan (3) strategi penggunaan tindak tutur direktif anak autis. Sumber data penelitian adalah anak autis di sekolah autis dan sekolah inklusi di kota Malang. Dalam penelitian ini, peneliti memposisikan diri sebagai instrumen utama. Sebagai instrumen utama, dalam melakukan penelitian ini, peneliti memegang peran kunci, baik dalam pengumpulan data, 
penganalisisan data, maupun penyimpulan temuan penelitian. Teknik pengumpulan data yang digunakan dalam penelitian ini adalah teknik perekaman dan pengamatan. Teknik analisis data yang digunakan dalam penelitian ini adalah model interaktif. Pengumpulan dan analisis data dikerjakan secara serempak, bolak-balik, dan berkali-kali sampai titik jenuh, sesuai dengan keperluan dan kecukupan. Analis data untuk menghasilkan sebuah pemahaman yang mendalam dan utuh tentang bentuk, fungsi, dan strategi tindak tutur direktif anak autis.

\section{HASIL DAN PEMBAHASAN}

Bentuk Tindak Tutur Direkif Anak Autis dalam Interaksi Pembelajaran di Kelas

Tindak tutur direktif merupakan tindak tutur yang mengekspresikan keinginan penutur agar mitra tutur melakukan suatu tindakan seperti yang disebutkan di dalam tuturannya. Tindak tutur direktif merupakan salah satu bentuk tindak tutur yang digunakan anak autis ketika berkomunikasi dengan mitra tutur. Dari hasil analisis data penelitian ini ditemukan bahwa bentuk tindak tutur direktif anak autis meliputi tindak tutur permintaan, tindak tutur perintah, dan tindak tutur larangan. Ketiga jenis tindak tutur tersebut dipaparkan sebagai berikut.

\section{Tindak Tutur Permintaan}

Tindak tutur permintaan merupakan salah satu bentuk tindak direktif. Tindak tutur permintaan ini dimaksudkan penutur agar mitra tutur memenuhi keinginannya seperti yang dimaksudkan dalam tuturannya. Melalui tindak tutur permintaan ini penutur meminta mitra tutur agar melakukan sesuatu, sesuai dengan keinginan penutur.

Tindak tutur permintaan yang ditemukan dalam penelitian ini sebagaimana tampak pada kutipan berikut.

[1] G : "Apakah bajunya Bu Vivi warna biru?". (1) (memegang baju war- na coklat yang dipakai sambil melihat Anton).

AA : "Sakitkepala". (2) "Sudah-sudah!". (3) "Sakit kepala". (4)

G : Ton, apakah bajunya Bu Vivi warna biru? (5) (memegang baju berwarna coklat)

AA : Tidak. (6) (memegang baju menirukan Bu Vivi).

Pada tuturan (2) dan (4), ungkapan Anton "Sakit kepala". merupakan bentuk tindak tutur permintaan. Dikatakan sebagai tindak tutur permintaan karena melalui tindak tutur tersebut penutur meminta mitra tutur untuk melakukan sesuatu seperti yang dimaksud dalam tindak tuturnya. Melalui tindak tutur tersebut, Anton sebagai penutur meminta $\mathrm{Bu}$ Vivi untuk menghentikan pertanyaannya dengan mengatakan sakit kepala. Tindak tutur permintaan tersebut diungkapkan anak autis dengan kalimat sederhana ketika proses pembelajaran konsep warna sedang berlangsung (Handoko, 2004).

Selain tindak tutur tersebut, tuturan (3) juga merupakan tindak tutur permintaan. Tindak tutur Anton tersebut dikatakan sebagai tindak tutur permintaan karena melalui tindak tutur tersebut Anton berharap $\mathrm{Bu}$ Vivi berhenti memberikan pertanyaan kepada dia. Tindak tutur permintaan tersebut disampaikan secara langsung dengan mengatakan "Sudahsudah!". disertai alasan dengan mengatakan "Sakit kepala". seperti terlihat pada tuturan (2) dan tuturan (4). Walaupun dituturkan dengan kalimat sederhana, mitra tutur mengatahui maksud yang terkandung dalam tindak tutur tersebut (Priyatna, 2010).

\section{Tindak Tutur Perintah}

Selain tindak tutur permintaan, tindak tutur perintah merupakan salah satu bentuk tindak direktif anak autis dalam interaksi pembelajaran di kelas. Sebagai salah satu bentuk tindak direktif, tindak 
tutur perintah digunakan penutur untuk memerintah mitra tutur agar melakukan sesuatu seperti dimaksudkan dalam tuturannya. Melalui tindak tutur perintah mitra tutur melakukan tindakan karena tindak tutur yang diungkapkan oleh penutur dalam tuturannya.

Hasil analisis data ditemukan penggunaan tindak tutur perintah yang digunakan anak autis sebagaimana terungkap pada kutipan berikut.

[1] G : "Kalau Desi, Bu Irma punya uang tiga belas keping uang lima ratusan".(1)

AA : "enam" (2)

G : "Berapa?" (3)

AA : "Enam ribu lima ratus". (4)

G : "Enam ribu lima ratus". (5) "Lama-lama hafal dan paham ya mbak Desi". (6) "Oke pintar". (7) "Saya hapus, boleh?". (8)

AA : "Hapus!"(9)

Pada tuturan (9) “Hapus!" yang diungkapkan Desi tersebut merupakan bentuk tindak tutur perintah. Dikatakan sebagai tindak tutur perintah karena melalui tindak tutur tersebut, Desi berharap kepada $\mathrm{Bu}$ Irma sebagai mitra tutur melakukan tindakan sebagaimana yang dimaksudkan dalam tindak tutur tersebut. Tindak tutur perintah tersebut diungkapkan Desi tanpa memperhatikan status dan perannya sebagai penutur ketika berkomunikasi dengan $\mathrm{Bu}$ Irma sebagai mitra tutur yang dalam hal ini adalah gurunya. Anak autis tidak memahami aturan yang demikian, sehingga dalam tindak tutur perintah tersebut, Desi tidak menggunakan kata "tolong" saat mengungkapkan perintah kepada Bu Irma sebagai mitra tuturnya. Desi memerintah gurunya dengan mengatakan "hapus!", untuk menghapus jawabannya yang keliru tanpa memperhatikan etika dalam berkomunikasi. Desi tidak mempertimbangkan bagaimana kedudukannya dalam peristiwa tutur tersebut.
Selain itu pada kutipan [9] tersebut tindak tutur yang diungkapkan anak autis dituturkan dengan tidak mempertimbangkan perbedaan status dan peran institusional antara guru dan siswa. Kutipan tersebut merupakan representasi bentuk tindak tutur perintah yang dilakukan anak autis. Seperti halnya penggunaan tindak tutur perintah untuk temannya, tindak tutur perintah (9) tersebut memerintah secara langsung apa yang diinginkannya kepada gurunya. Nani tidak menggunakan modalitas "tolong" untuk memerintah gurunya.

\section{Tindak Tutur Larangan}

Tindak tutur larangan merupakan bentuk tindak direktif yang digunakan anak autis dalam interaksi pembelajaran di kelas. Pada dasarnya tindak tutur larangan juga berisi perintah, tetapi perintah negatif, yakni agar mitra tutur tidak melakukan sesuatu.

Hasil analisis data ditemukan beberapa bentuk tindak tutur larangan yang digunakan anak autis dalam interaksi pembelajaran di kelas. Hal dimaksud dipaparkan sebagai berikut.

[1] G : "Siapa ini Mbak Desi?". (1) (menunjukkan gambar kepada Desi)

AA : "Dewi". (2)

G : "Dewi, di mana ini?". (3)

AA1: "Di Sekolah". (4)

AA2: "Di sekolah". (5) (anak autis yang lain tidak ditunjuk ikut menjawab.

G : “Dini!". (6) (melarang anak autis yang tidak ditanya ikut menjawab).

AA1: "Ssssstt". (7) (menutup mulutnya sendiri dengan jari telunjuk)

Kutipan pada tuturan (7) tersebut merupakan representasi bentuk tindak tutur larangan. Dini merepresentasikan bentuk tindak tutur larangan pada tuturan (7) tidak menggunakan kata "jangan", namun dengan menggunakan kata dan isyarat 
singka "Ssssstt". Tindak tutur tersebut dimaksudkan anak autis sebagai tindak tutur larangan kepada dirinya sendiri supaya diam dan tidak ikut menjawab pertanyaan yang ditujukan kepada temannya. Tinak tutur pada tuturan (7) tersebut merupakan tanggapan tindak tutur guru yang dipaparkan pada tuturan (6).

Mengetahui temannya tidak segera menjawab pertanyaan yang diajukan gurunya, Dini yang merasa mengetahui jawabannya, segera menjawab pertanyaan tersebut. Tindak tutur yang dituturkan Dini tersebut merupakan bentuk tindak tutur larangan yang ditujukan untuk dirinya sendiri. Sudah menjadi kebiasaan Dini, kalau temannya ditanya, dia ikut menjawab. Walaupun gurunya hanya memanggil namanya, Dini sudah memahami ungkapan gurunya tersebut dan melarang dirinya sendiri untuk diam dengan hanya mengungkapkan kata tunggal yakni "Sstt".

Tindak tutur larangan tersebut digunakan anak autis ketika menanggapi tuturan gurunya seperti dipaparkan pada tuturan (6). Walaupun guru hanya memanggil namanya, dia sudah bisa memahami dan dia secara langsung melarang dirinya sendiri supaya diam dan tidak ikut menjawab pertanyaan gurunya. Dalam merepresentasikan tindak tutur larangan, biasanya penutur memperhatikan aspek sosial dan budaya, seperti status kerabat, para partisipan, hubungan peran antarpartisipan, dan hak serta kewajiban yang sesuai dengan lingkungan tempat anak itu tumbuh dan berkembang. Namun anak autis dalam tuturan tersebut, tidak mempertimbangkan aspek-aspek tersebut. Dalam tuturan tersebut, anak autis menyatakan tindak tutur larangan kepada dirinya sendiri.

Fungsi Komunikatif Tindak Tutur Direktif Anak Autis dalam Interaksi Pembelajaran di Kelas

Hasil analisis data ditemukan beberapa fungsi komunikatif tindak tutur direktif anak autis. Fungsi komunikatif tindak tutur direktif anak autis yang ditemukan dalam penelitian ini meliputi: fungsi meminta, fungsi memerintah, dan fungsi melarang. Temuan ketiga fungsi komunikatif tindak tutur direktif anak autis tersebut sebagaimana disajikan di bawah ini.

\section{Fungsi Meminta}

Bahasa memiliki bermacam-macam fungsi, salah satu fungsi Bahasa adalah fungsi direktif. Salah satu fungsi direktif bahasa adalah fungsi meminta. Fungsi meminta merupakan salah satu fungsi tindak tutur direktif yang dimaksudkan penutur agar mitra tutur melakukan sesuatu seperti yang terkandung dalam tuturannya atau penutur diberi atau mendapat sesuatu dari mitra tuturnya.

Anak autis mengalami kesulitan dalam mengungkapkan tuturan untuk menyampaikan keinginannya kepada mitra tutur karena keterbatasan kemampuan yang dimilikinya. Dalam interaksi pembelajaran di kelas, untuk memenuhi keinginannya sesuai dengan kebutuhanannya anak autis menggunakan tindak tutur direktif yang berfungsi meminta. Bagi anak autis untuk bisa mengungkapkan tindak tutur yang berfungsi untuk meminta sesuatu tidaklah mudah. Mereka memiliki cara tersendiri untuk menyampaikan maksud tindak tuturnya. Anak autis Anak autis yang sudah bisa berkomunikasi, biasanya menyampaikan maksud tuturannya dengan kalimat yang singkat-singkat.

Hasil analisis data ditemukan fungsi meminta dalam tuturan lisan anak autis sebagaimana tampak pada kutipan [1] berikut.

[1] G : "Apakah bajunya Bu Vivi warna biru?". (1) (memegang baju warna coklat yang dipakai sambil melihat Anton).

AA : "Sakitkepala". (2) "Sudah-sudah!". (3) "Sakit kepala". (4)

G : Ton, apakah bajunya Bu Vivi warna biru? (5) (memegang baju 
berwarna coklat)

AA : Tidak. (6) (memegang baju menirukan Bu Vivi/gurunya).

Dalam kutipan [1] tersebut terungkap bahwa salah satu fungsi komunikatif tindak tutur direktif anak autis adalah fungsi meminta. Dikatakan berfungsi meminta karena berdasarkan tindak tutur yang diungkapkan tersebut, anak autis menghendaki sesuatu dilakukan oleh mitra tuturnya. Pada tuturan (3), pernyataan anak autis "Sudah..sudah!" mengandung maksud agar Bu Vivi sebagai mitra tutur menghentikan tuturannya dan tidak terus memberikan pertanyaan kepadanya. Dalam mengungkapkan maksud tuturannya, anak autis tersebut hanya menggunakan ujaran satu kata yang diulang. Dia tidak mengungkapkan maksud tuturannya dengan kalimat yang lengkap.

\section{Fungsi Memerintah}

Fungsi memerintah merupakan salah satu fungsi tindak tutur direktif anak autis yang digunakan dalam interaksi pembelajaran di kelas. Fungsi memerintah merupakan salah satu fungsi tindak tutur direktif yang digunakan anak autis dalam interaksi pembelajaran di kelas dimaksudkan agar mitra tutur melakukan sesuatu seperti dimaksudkan dalam tindak tuturnya.

Hasil analisis data ditemukan fungsi memerintah yang digunakan anak autis dalam interaksi pembelajaran di kelas. Hal dimaksud sebagaimana terungkap dalam kutipan berikut.

[1] G : "Kalau Desi, Bu Irma punya uang tiga belas keping uang lima ratusan".(1)

AA : "enam" (2)

G : "Berapa?" (3)

AA : "Enam ribu lima ratus". (4)

G : "Enam ribu lima ratus". (5) "Lama-lama hafal dan paham ya mbak Desi". (6) "Oke pintar". (7) “Saya hapus, boleh?”. (8)

\section{AA : "Hapus!"(9)}

Pada tindak tutur (9) "Hapus!" yang diungkapkan Desi tersebut merupakan tindak tutur yang berfungsi memerintah. Dikatakan sebagai tindak tutur memerintah karena melalui tindak tutur tersebut, Desi berharap kepada Bu Irma sebagai mitra tutur melakukan tindakan sebagaimana yang dimaksudkan dalam tindak tutur tersebut. Tindak tutur berfungsi memerintah diungkapkan Desi tanpa memperhatikan status dan perannya sebagai penutur ketika berkomunikasi dengan Bu Irma sebagai mitra tutur.

Fungsi memerintah diungkapkan anak autis melalui tindak tutur perintah dipaparkan pada tuturan (9). Tindak tutur tersebut diungkapkan anak autis tanpa memperhatikan etika dalam berkomunikasi dan perbedaan status serta peran institusional antara guru dan siswa dalam interaksi pembelajaran di kelas (Veskarisyanti, 2008). Tindak tutur "Hapus!" tersebut merupakan representasi fungsi tindak tutur memerintah yang diungkapkan anak autis kepada mitra tuturnya. Seperti halnya penggunaan tindak tutur berfungsi memerintah kepada temannya, tindak tutur (9) tersebut berfungsi memerintah secara langsung diungkapkan anak autis dengan mengatakan apa yang diinginkannya kepada gurunya. Walaupun dengan gurunya, Desi tidak menggunakan modalitas "tolong" untuk memerintah gurunya.

\section{Fungsi Melarang}

Fungsi melarang diungkapkan penutur dengan maksud agar mitra tutur tidak melakukan suatu tindakan seperti yang terkandung dalam tindak tuturnya. Fungsi melarang disampaikan penutur dalam tuturannya untuk memerintahkan supaya mitra tutur tidak melakukan sesuatu atau tidak memperbolehkan berbuat sesuatu. Tindak tutur melarang atau membatasi pada dasarnya adalah 
perintah atau suruhan agar mitra tutur tidak melakukan sesuatu.

Fungsi melarang yang ditemukan dalam penelitian ini sebagaimana tampak pada kutipan berikut.

[1] G : "Siapa ini Mbak Desi?". (1) (menunjukkan gambar kepada Desi)

AA : "Dewi". (2)

G : "Dewi, di mana ini?".

AA1: “Di Sekolah”. (4)

AA2: "Di sekolah". (5) (anak autis yang lain tidak ditunjuk ikut menjawab.

G : “Dini!". (6) (melarang anak autis yang tidak ditanya ikut menjawab).

AA1: "Ssssstt". (7) (menutup mulutnya sendiri dengan jari telunjuk)

Berdasarkan kutipan tersebut terungkap tindak tutur anak autis yang berfungsi untuk melarang. Pada tuturan (7) di atas, ungkapan "Sstt!" yang dituturkan Dini berfungsi melarang. Dikatakan mengandung fungsi melarang karena maksud tindak tutur tersebut adalah agar tidak melakukan sesuatu. Tindak tutur berfungsi melarang tersebut diungkapkan Dini ditujukan kepada dirinya sendiri. Peristiwa tutur tersebut berlangsung pada saat Bu Atik melakukan kegiatan tanya jawab kepada anak autis dalam proses pembelajaran di kelas.

Tindak tutur yang berfungsi melarang tersebut dimaksudkan untuk melarang dirinya sendiri untuk tidak ikut menjawab pertanyaan yang ditujukan kepada temannya. Sudah menjadi kebiasaan Dini, kalau temannya ditanya, dia ikut menjawab. Pada tuturan (6) Bu Atik mengingatkan Dini agar tidak menjawab pertanyaan dengan memanggil nama "Dini!". Berdasarkan tindak tutur (6) Dini mengungkapkan tindak tutur berfungsi melarang seperti dipaparkan pada tuturan (7). Walaupun hanya berupa kata tunggal. "Sstt". namun mitra tutur mengetahui bahwa tuturan tersebut berfungsi melarang.
Strategi Penggunaan Tindak Tutur Direktif Anak Autis dalam Interaksi Pembelajaran di Kelas

Strategi penggunaan tindak tutur merupakan teknik sistematis yang digunakan penutur untuk mengekspresikan ide dan gagasannya ketika berkomunikasi dengan mitra tutur. Strategi penggunaan tindak tutur direktif anak autis dalam interaksi pembelajaran di kelas dilakukan secara langsung dan ada kalanya secara tidak langsung.

Hasil analisis data ditemukan strategi penggunaan tindak tutur direktif anak autis dalam interaksi pembelajaran di kelas dengan menggunakan strategi langsung dan strategi tidak langsung. Hal dimaksud dipaparkan sebagai berikut.

\section{Strategi Langsung}

Berdasarkan hasil analisis data strategi langsung penggunaan tindak tutur direktif anak autis dalam interaksi pembelajaran di kelas yang ditemukan dalam penelitian ini sebagaimana tampak pada kutipan berikut.

[1] G : "Apa ini?" (1) (guru bertanya sambil menunjukkan buku)

AA : "Buku”. (2)

G : "Apa ini" (3) (sambil memukulmukul meja)

AA : Diam tidak menghiraukan pertanyaan guru.

G : "Apa ini?" (4) (menunjuk meja)

AA : "Meja". (5)

G : "Apa ini?". (6) (guru bertanya sambil memegang pensil)

AA : "Makan-makan!"(7)

G : “Apa ini?". (8)

Pada tuturan (7) tersebut anak autis meminta mitra tuturnya untuk mengakhiri pertanyaan yang ditujukan kepadanya dengan mengatakan "Makan-makan!". Permintaan dengan menggunakan strategi langsung diungkapkan anak autis tersebut karena dia merasakan lapar dan sudah waktunya istirahat untuk makan siang. 
Kemampuan berkomunikasi anak autis masih sangat terbatas. Mereka umumnya mau berkomunikasi dengan mitra tutur jika membutuhkan sesuatu untuk pemenuhan kebutuhan dirinya (Saraswati, 2004). Seperti pada kutipan di atas, karena perutnya terasa lapar, maka untuk memenuhi kebutuhan tersebut, dia langsung mengungkapkannya dalam bentuk tuturan permintaan makan kepada gurunya. Walaupun pada saat tuturan itu diungkapkan, guru sedang mengajukan pertanyaan kepadanya.

\section{Strategi Tidak Langsung}

Strategi tidak langsung merupakan salah satu strategi penggunaan tindak tutur direktif anak autis dalam interaksi pembelajaran di kelas. Berdasarkan hasil analisis data ditemukan strategi penggunaan tindak tutur tidak langsung dalam interaksi pembelajaran anak autis.

Hasil analisis data ditemukan strategi penggunaan tidak langsung dalam interaksi pembelajaran anak autis sebagaimana tampak pada kutipan [1] berikut.

[1] G : "Apakah bajunya Bu Vivi warna biru?". (1) (memegang baju warna coklat yang dipakai sambil melihat Anton).

AA : "Sakitkepala". (2) "Sudah-sudah!". (3) "Sakit kepala". (4)

G : Ton, apakah bajunya Bu Vivi warna biru? (5) (memegang baju berwarna coklat)

AA : Tidak. (6) (memegang baju menirukan Bu Vivi/gurunya).

Selain strategi langsung, ada kalanya anak autis menggunakan strategi tidak langsung untuk mengungkapkan sesuatu yang diingikannya. Hal ini dapat dilihat pada tuturan (2) dan (4). Tindak tutur permintaan yang berfungsi meminta mitra tutur melakukan sesuatu yang diinginkan penutur dalam hal ini anak autis diungkapkan dengan mengatakan "Sakit kepala". Tindak tutur permintaan terse- but diungkapkan anak autis secara tidak langsung. Melalui tindak tutur tersebut, Anton meminta kepada Bu Vivi secara tidak langsung untuk tidak mengajukan pertanyaan kepada dirinya dilakukan secara tidak langsung. Dengan mengajukan permintaan tersebut Anton berharap Bu Vivi tidak memberi pertanyaan lagi.

\section{SIMPULAN}

Dari temuan dan bahasan di atas dapat disimpulkan sebagai berikut. Pertama, bentuk tindak tutur direktif anak autis yang ditemukan dalam penelitian ini meliputi tindak tutur permintaan, tindak tutur perintah, dan tindak tutur larangan. Kedua, fungsi komunikatif tindak tutur direktif anak autis meliputi fungsi meminta, fungsi memerintah, dan fungsi melarang. Ketiga, strategi penggunaan tindak tutur direktif anak autis meliputi strategi langsung dan strategi tidak langsung.

\section{UCAPAN TERIMA KASIH}

Artikel ini diangkat dari penelitian yang dilaksanakan pada tahun 2014 dengan anggaran DIPA Direktorat Jenderal Pendidikan Tinggi Kementerian Pendidikan dan Kebudayaan. Oleh karena itu ucapan terima kasih disampaikan kepada Direktorat Jenderal Pendidikan Tinggi Kementerian Pendidikan dan Kebudayaan yang telah mendanai penelitian ini. Selanjutnya, ucapan terima kasih disampaikan kepada dua reviewer yang telah membaca, mengoreksi, dan memberi masukan terhadap artikel ini.

\section{DAFTAR PUSTAKA}

Cummings, L. 2009. Clinical Pragmatics. Cambridge: Cambridge University Press.

Dompas, O. Y. 2008. Menaklukkan Autis: Perjalanan Hidup Penuh Tantangan Penderita Autis. Yogyakarta: Tabora Media. 
Handoko. 2004. Autisma: Petunjuk Praktis dan Pedoman Materi Untuk Mengajar Anak Normal, Autis dan Perilaku Lain. Jakarta: Buana Ilmu Populer.

Maulana, M. 2007. Anak Autis: Mendidik Anak Autis dan Gangguan Mental Lain Menuju Anak Cerdas dan Sehat. Jogjakarta: Katahati.

Peeters, T. 2004. Autisme: Hubungan Pengetahuan Teoritis dan Intervensi Pendidikan Bagi Penyandang Autis. Jakarta: Dian Rakyat.

Prasetyono, D. S. 2008. Serba Serbi Anak Autisn (Autisme dan Gangguan Psikologis Lainnya: mengenal, menangani, dan Mengatasinya dengan Tepat dan Baik). Jogjakarta: DIVA Press.

Priyatna, A. 2010. Amazing Autism: Memahami, Mengasuh, dan mendidik Anak Autis. Jakarta: Gramedia.

Puspita, D. 2008. Warna-warni Kehidupan: Ketika Anak Autis Berkembang Remaja. Jakarta: Yayasan Autisme Indonesia.
Saraswati. 2004. Meniti Pelangi: Perjuangan Seorang Ibu Yang Tak Kenal Menyerah dalam Membimbing Putranya Keluar dari Belenggu ADHD dan Autisme. Jakarta: Gramedia.

Sumarti, E. 2012. Kompetensi Komunikatif dalam Tuturan Lisan Anak Autis. Disertasi. Malang: PPS Universitas Negeri Malang.

William, D. 2004. Dunia di Balik Kaca: Kisah Nyata Seorang Gadis Autistik. Bandung: Qanita Misan Pustaka.

Veskarisyanti, G. A. 2008. 12 Terapi Autis Paling Efektifdan Hemat: untuk Autisme, Hiperaktif, dan Retardasi Mental. Yogyakarta: Pustaka Anggrek.

Yatim, F. 2003. Autisme: Suatu Gangguan Jiwa pad Anak-anak. Jakarta: Pustaka Populer Obor. 